\title{
The usefulness of different wood species for bow manufacturing
}

\author{
Waldemar Moliński, Przemysław Mania $\bowtie$, Gabriel Tomczuk \\ Poznań University of Life Sciences, Department of Wood Science, Wojska Polskiego 38/42, 60-627 Poznań, Poland, \\ phone: +48 61 8487448, e-mail: pmania@up.poznan.pl
}

\begin{abstract}
The aim of this study was to define the density and selected mechanical parameters of wood used for bow production at present, and in the past. Properties such as modulus of elasticity, bending strength and energy accumulation were determined for 11 species of wood. The analysis of results revealed that in the past, the wood used for the production of bows was not always most suitable for this application.
\end{abstract}

\section{KEY WORDS}

bow, wood, modulus of elasticity, elastic strain energy

\section{INTRODUCTION}

Many researchers of history of mankind believe that the story of bow dates back to the Paleozoic era (Stone Age), to a period that ended around the year $8000 \mathrm{BC}$. This is confirmed by the images of archers discovered in the Spanish caves, dating back to the upper Paleozoic. Arrowheads made of stones provide evidence on which the archaeologists have based their theories. Amongst the ancient civilizations, the Egyptians were the first great archers and used bow as their main weapon in the struggle of war. Although the flint arrowheads were not uncommon, the most commonly used material was bronze. At that time, the Israelites used bows made of reed, wood and horn - both in war and for hunting. In ancient Europe, the Romans used short composite bows, while the German tribes used longbows. In the fourteenth century during the Hundred Years War between England and France, bows were accepted as effective weapons. In many battles fewer English troops, composed mainly of archers defeated more numerous branch of the French composed of knights, infantry and hired crossbowmen (Massey 2002). In the sixteenth century, with developments in the production of firearms in Europe, bows were replaced with firearms. Today, archery is becoming more popular due to the popularization of historical reconstruction movements, and also as a sport and a source of entertainment.

Tensile strength is a function of the distance which is measured from the point of the arrow on the string when it is at the resting position to the final position, when it is a fully tensioned arc. The strength at the maximum tensioned bow is called the draw weight, or weight and is expressed in kilograms $(\mathrm{Kg})$. The release of arrow occurs at the moment of relaxation by the archer's grip on the string, and the energy accumulated in the elastic limbs is passed by the string to the arrow, which 
gives it a boost. The arms of bow accumulate energy during bending, which is inserted in its deformation, and after removal of the load rapidly give this energy back, returning to the original shape. The density of wood in this case is important because greater the mass of arms, greater will be the accumulation of energy which gives acceleration to the bow arms to return their initial positions.

Theoretically, it is assumed that tensile strength of the bow increases linearly as a function of displacement of bow string. In this case, the accumulated energy is expressed by the below mentioned formula:

$$
E=\frac{1}{2} F_{\max } \cdot \alpha
$$

where: $F_{\max }-$ maximum force needed to tension a bow to a full draw.

The efficiency of bow determines the ratio of energy inserted in bow stretch to energy transferred to the arrow. It depends not only on the elastic properties of the used material (species of wood), but also on the size and shape of the elastic limbs. Different wood species in different ways reflect the accumulated elastic energy. The most important parameter characterizing a good wood for the production of bows is the amount of energy value it is able to accumulate in its limbs until its destruction. This parameter determines the value of energy transmitted to the arrow. Furthermore, woods with high capabilities for accumulation of energy are less vulnerable to damage. Thus, the wood with the greatest ability to accumulate mechanical energy is the best for this type of application.

The previous literature reports indicate that the best species of wood for manufacturing bows are those that have the highest stiffness. According to Duff (1927), the wood which is best suited for the production of the bow is yew (Taxus baccata) and Osage orange (Maclura pomifera). Comstock (2000) stated that a lot of wood species are suitable to produce bows, for example, elm (Ulmus), hickory (Carya), ash (Fraxinus), oak (Quercus) and many others. Nawalny (2008) and Jankowski (2002) reported that the types of wood that can be used to manufacture bow are locust (Robinia), ash (Fraxinus), maple (Acer), yew (Taxus) and hickory (Carya).
The main aim of this study was to determine the physic-mechanical parameters of wood, mainly in terms of their density and ability to accumulate mechanical energy that is the basic criteria for determining the suitability of this material for manufacturing bows. These criteria have been adopted on the basis of the study of available literature.

\section{Material AND methods}

The experimental material used in the study was wood obtained from craftsman producing bows, and the resources of the Department of Wood Science of Poznan University of Life Sciences. The study was conducted on wood yew (Taxus baccata L.), hickory (Carya spp.), European ash (Fraxinus excelsior L.), European birch (Betula pubescens Ehrh.), European beech (Fagus sylvatica L.), common alder (Alnus glutinosa L.), Norway maple (Acer platanoides L.), European oak (Quercus robur L.), smooth leaved elm (Ulmus minor Mill.), ovangkol (Guibourtia ehie (A.Chev.) J.Lèon.) and the western red cedar (Thuja plicata Donn. Ex D. Don.). Further in the text and figures, the common names of the wood species will be used. Due to the fact that wood used in a bow is subjected to bending strength, it was decided to carry out a determination of mechanical parameters of the wood using a three-point bending test (based on PN-77/D-04103). Based on the limited amount of research material obtained from bow producers, we decided to carry out this test on samples with dimensions of $10(\mathrm{~T}) \times 10(\mathrm{R}) \times 150(\mathrm{~L}) \mathrm{mm}$. Before the determinations of mechanical parameters, wood density was determined (PN -77/D-04101).

Experimental tests were carried out using the equipment ZWICK ZO50TH wood testing machine. In this machine, the software allowed us to calculate the modulus of elasticity, elastic energy and destruction energy, the bending strength of wood or deformation at the time of destruction. The distance between supports during the experiment was $120 \mathrm{~mm}$, and the load was applied midway, on the radial surfaces. After determination of wood bending strength, the moisture content of wood was also found using the gravimetric method (PN-77/D-04100). 


\section{Results}

Wood density $(\rho)$, bending strength $\left(F_{b}\right)$, modulus of elasticity (MOE), elastic strain energy $\left(U_{e}\right)$ and work to maximum load (WML) of wood with moisture content (MC) of approximately $8 \%$ are shown in Table 1 . The table contains average values, calculated for different numbers of samples used for the test. The number of samples depended on the amount of material obtained from the manufacturer arcs.

Table 1. Summary of selected parameters of the tested types of wood at $\mathrm{MC}=8 \%$

\begin{tabular}{|c|c|c|c|c|c|c|}
\hline \multirow[b]{2}{*}{ Wood species } & \multirow[b]{2}{*}{ 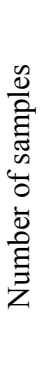 } & \multicolumn{5}{|c|}{$\begin{array}{l}\text { Selected physico-mechanical } \\
\text { parameters }\end{array}$} \\
\hline & & 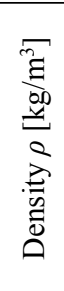 & 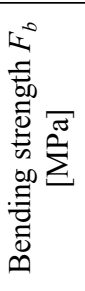 & 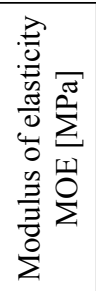 & 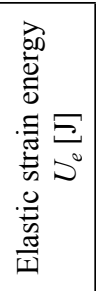 & 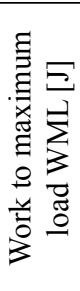 \\
\hline Yew & 8 & 560 & 116 & 6530 & 0.226 & 3.02 \\
\hline European ash & 7 & 690 & 147 & 11557 & 0.247 & 1.96 \\
\hline Hickory & 4 & 880 & 161 & 9384 & 0.207 & 5.80 \\
\hline Ovangkol & 2 & 775 & 198 & 15910 & 0.382 & 2.64 \\
\hline European oak & 8 & 730 & 140 & 11840 & 0.208 & 1.76 \\
\hline European birch & 10 & 690 & 161 & 13450 & 0.221 & 2.42 \\
\hline Common alder & 8 & 585 & 121 & 10319 & 0.252 & 1.45 \\
\hline European beech & 8 & 700 & 130 & 10511 & 0.159 & 2.16 \\
\hline Norway maple & 8 & 645 & 148 & 12392 & 0.257 & 2.29 \\
\hline Western red cedar & 8 & 405 & 86 & 7095 & 0.144 & 1.03 \\
\hline Smooth leaved elm & 8 & 575 & 128 & 9225 & 0.238 & 1.79 \\
\hline
\end{tabular}

The collected data, as shown in Table 1 above, allowed us to align the wood species in terms of the decreasing values of the studied parameters. The analyzed samples of wood were characterized by an average density similar to that described by Wagenführ (2007) or Krzysik (1978). The highest average density was found in hickory wood $\left(880 \mathrm{~kg} / \mathrm{m}^{3}\right)$, while the lowest was found in red cedar wood $\left(405 \mathrm{~kg} / \mathrm{m}^{3}\right)$. The red cedar wood is not used for manufacturing of bows, but we used it intentionally in our research in order to expand the density scale of the tested material. The wood of yew and elm were most frequently mentioned in the literature as the material used for the production of bows. Both types of wood were characterized by a similar density, which was also one of the lowest among all analyzed samples. The examined wood of yew was characterized by less than $100 \mathrm{~kg} / \mathrm{m}^{3}$ than this wood species in the aspect of using it for manufacturing of bows (Keunecke et al. 2008, 2009).

In the case of modulus of elasticity, the highest values were showed by ovangkol wood. A slightly different alignment of the test wood by decreasing the values of modulus of elasticity than density indicated that density of wood was not the perfect determinant of its elastic properties. The relationship of density of the investigated wood with modulus of elasticity is presented in Figure 1.

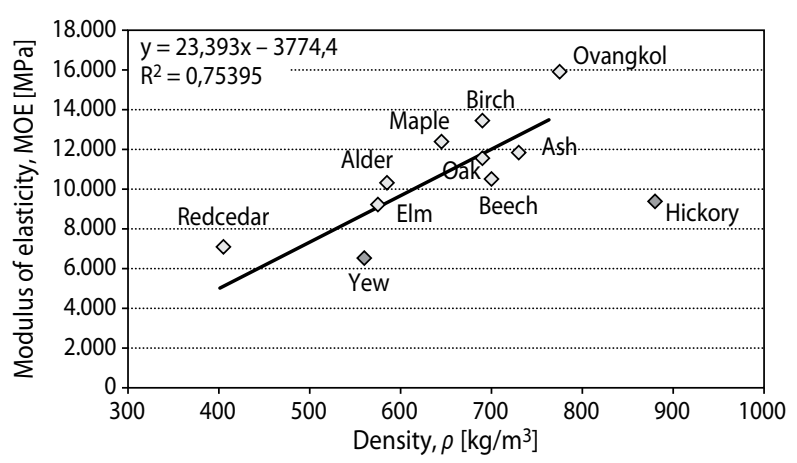

Figure 1. Relationship between modulus of elasticity and density of tested wood species

Data contained in this figure showed that in case of hickory and yew wood, the values of modulus of elasticity strongly differed from the trend, approximating the experimental data. Yew wood was characterized by significantly lower elastic modulus values than was apparent from its density, which could have been caused by a greater micro fibril angle in the cell wall of the tracheids. This parameter for yew wood was much lower than, for example, described by Wagenführ (2007). This supposition was also confirmed earlier by Keunecke et al. in several of their works (2007a, 2007b, 2008a and 2009). For this reason, the modulus of elasticity can not to be the only determinant indicating the suitability of wood for manufacturing bows (Bjurhager et al. 2013).

The data in Table 1 indicates that the highest value of work to maximum load was characterized by hickory wood, followed by yew wood, while the smallest was 
seen in red cedar and alder. Elm wood, which is traditionally used to make bows, showed on an average a $40 \%$ lower value of energy needed to destroy than yew wood, as ash wood. Hickory wood showed up to $90 \%$ more WML than yew wood. Most probable reasons for the wide variation of this parameter can be discerned in the diversified structure of the analyzed species. Hence, density of wood is not a good predictor of this parameter according to the data from Figure 2.

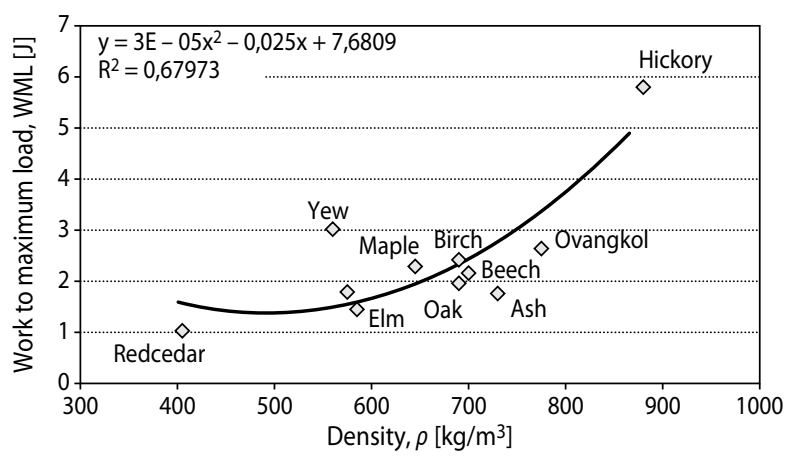

Figure 2. Relationship between work to maximum load and density of tested types of wood

The highest capacity for accumulation of mechanical energy was showed by hickory wood, but it had the highest density value also. It was found that yew wood, which had a relatively low density, had a high value of work to maximum load. Similar observations were found in the works of Keunecke et al. (2007a, 2007b, 2008a, 2008b and 2009), who translated this fact on the ultra-structure of cell wall. Moreover, yew wood had more than $10 \%$ of extractives, the presence of which in the cell wall may contribute to the reduction of internal friction, thereby, further enhancing the accumulation of mechanical energy.

Figure 3 shows the range of average values of bending crushing strain $\left(\mathrm{f}_{\max }\right)$ for the various types of wood that were studied. Attention should be paid to the fact that a significant difference of deformation at the time of destruction in hickory and yew wood were shown in comparison with other types of wood. In hickory and yew wood, the strains were much higher than in other species, although hickory and yew wood characterized practically extreme values of density.

A high value of strain at the moment of destruction indicates a high resistance to wood cracking. In such a case, much of the mechanical energy is converted into work of deformation, which makes the material less brittle, in other words, more ductile from wood which gets destroyed at lower strain values. Relatively low value of strain was registered in ash wood, which is currently recommended for production of bows.

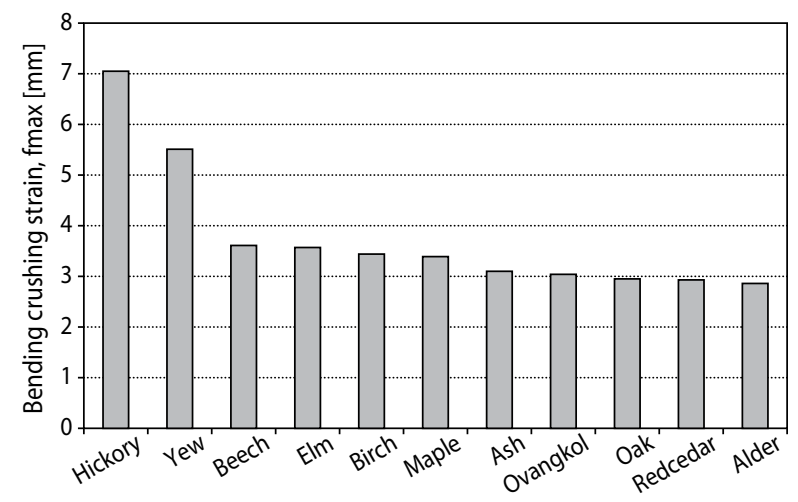

Figure 3. Bending, crushing strain in tested types of wood

\section{Conclusions}

1. Both yew and hickory wood were characterized by a significantly lower modulus of elasticity than it would result from their density. At the same time, the wood of these species had the highest capacity for accumulation of mechanical energy.

2. Elm wood was characterized by significantly less capacity for accumulation of energy than yew wood, with comparable density, which created doubt as to the suitability of this species for production of bows.

3. Ash wood, which is often used in the manufacturing of bows for its ability to accumulate of mechanical energy, appeared to be worse than maple, birch and beech. It was also characterized by a relatively low value of strain.

\section{References}

Bjurhager I., Gamstedt K., Keunecke D., Niemz P., Bergglund L.A. 2013. Mechanical performance of yew (Taxus baccata) from longbow perspective. Holzforschung, 67 (7), 763-770. 
Comstock P. 2000. Other bow woods. The traditional bowyer's bible vol. 1. The Lyons Press, Guilford, 149-164.

Duff J. 1927. Bows and arrows how they are made for all kinds of target shooting. Macmilan Company, New York.

Jankowski J. 2002. Medieval wooden bow (in Polish). Replika, Zakrzewo.

Keunecke D., Evans R., Niemz P. 2009. Microstructural properties of common yew and Norway spruce determined with Silviscan. IAWA J. 30, 165-178.

Keunecke D., Hering S., Niemz P. 2008a. Three-dimensional elastic behaviour of common yew and Norway spruce. Wood Science and Technology, 42, 633-647.

Keunecke D., Niemz P. 2008b. Axial stiffness and selected structural properties of yew and spruce microtensile specimens. Wood Research, 53, 1-14.

Keunecke D., Märki C., Niemz P. 2007a. Structural and mechanical properties of yew wood. Wood Research, 52, 23-38.
Keunecke D., Sonderegger W., Pereteanu K., Lüthi T., Niemz P. 2007b. Determination of Young's and shear moduli of common yew and Norway spruce by means of ultrasonic waves. Wood Science and Technology, 41, 309-327.

Krzysik F. 1978. Wood science (in Polish). PWN, Warszawa.

Massey J. 2002. Tradition begins with the past. The traditional bowyer's bible vol. 2. The Lyons Press, Guilford, 11-18.

Nawalny Ł. 2008. Secrets of a wooden bow (in Polish). Wojskowa Drukarnia w Łodzi, Łódź.

PN-77/D-04100 Wood. Determination of moisture content (standard in Polish).

PN-77/D-04101 Wood. Determination of density (standard in Polish).

PN-77/D-04103 Wood. Determination of the static bending strength (standard in Polish).

Wagenführ R. 2007. Holzatlas. Fachbuchverlag Leipzig im Carl Hanser Verlag, München. 